\title{
In Search of a Monetary Constitution for Brazil
}

\author{
Em busca de uma constituição monetária para o Brasil
}

MARCIO RONCI****

RESUMO: O presente artigo examina vários episódios da história monetária do Brasil e de outros países, bem como as recentes evidências empíricas para analisar criticamente as duas principais propostas de constituição monetária do Brasil: quadro de moeda e propostas de bancos centrais independentes. Delineamos também uma constituição monetária inspirada no Projeto Monetário de Pandiá Calógeras (1926), com o único objetivo de esclarecer os princípios básicos envolvidos no desenho de uma constituição monetária destinada a controlar o poder de gerar dinheiro e conter a inflação: separação entre o poder de criar dinheiro e os agentes que determinam os gastos públicos; (b) um claro dinheiro monetário para restringir o poder de criar dinheiro; e (e) separação do poder de gerar dinheiro da regulamentação e supervisão dos bancos.

PALAVRAS-CHAVE: Constituição monetária; estabilização; teoria quantitativa da moeda; inflação; oferta de moeda.

ABSTRACT: The present paper examines various episodes of the monetary history of Brazil and other countries as well as the recent empirical evidence to look into critically the two principal proposals of monetary constitution for Brazil: currency board and independent central bank proposals. We outline also a monetary constitution inspired in the Pandiá Calógeras's Monetary Project (1926) with the only purpose of shedding light on the basic principles involved in the design of a monetary constitution aimed at controlling the power to create money and curbing inflation: (a) separation between the power to create money and the agents that determine public expenditure; (b) a clear monetary rule to constraint the power to create money; and (e) separation of the power to create money from the regulation and supervision of banks.

KEYWORDS: Monetary constitution; stabilization; quantity theory of money; inflation; money supply.

JEL Classification: E51; E58; E42.

\footnotetext{
* Economist at the Western Hemisphere Department, International Monetary Fund (IMF), Washington/ DC, United States. E-mail: mronci@imf.org.

** This paper benefited from discussions with Luis Eduardo Escobar, Giuseppe Tullio, Afonso Bevilaqua, Paulo Neuhaus, and Lauro Flavio de Faria. The opinions expressed are those of the author only and do not necessarily reflect those of the IMF.
} 
"The return to a stable currency requires a real change in the monetary constitution.... The first condition is that the power to create money should be completely independent from the agents that determine expenditure. "

Azeglio Ciampi (1981)

"Inflation is always and everywhere a monetary phenomenon."

Milton Friedman (1968, p. 39)

\section{INTRODUCTION}

In Brazil, the failure of various stabilization programs during 198294 has been associated with both insufficient fiscal adjustment and inflationary inertia of monetary contracts, principally wage contracts. However, these explanations do not seem satisfactory. Tullio \& Ronci (1996) argue that the missing piece in the explanation of Brazilian inflation is the lack of Central Bank independence and credibility to control money issue and curb inflation, while they do not find support for the inertia-hypothesis of inflation ${ }^{2}$. According to the authors, the quantity theory of money, amended for supply shocks, explains very well Brazilian inflation in the 1980s and early 1990s, and money growth is strongly influenced by fiscal deficits throughout the period given the presence of a central bank which is highly dependent on the government ${ }^{3}$.

This alternative view of Brazilian inflation suggests that a reform of the monetary constitution would facilitate the implementation of stabilization policies and, more importantly, maintain long-term monetary stability. The idea of a monetary constitution is broader than the idea of monetary policy: it consists of precise legal restrictions to control the power of creating money in order to reduce price level uncertainty ${ }^{4}$. One example of monetary constitution is the redeemable paper money system (Gold Standard and currency board) in which the monetary authority is constrained to keep the convertibility of the national currency into some asset it cannot create (gold or foreign currency) at a specified and fixed rate of exchange.

\footnotetext{
${ }^{1}$ Cited in Goodman (1992: 170).

${ }^{2}$ There is now sufficient empirical evidence showing that the inertia hypothesis of prices caused by wage and price indexation does not explain inflation completely and that wages and prices do respond to a slack in output. See also Barbosa and Pereira (1989).

${ }^{3}$ Using the turnover of Central Bank governors as a proxy for the institutional independence of the monetary authority, we verified that the situation had deteriorated a great deal: there were 11 governors in Brazil compared to only one governor in Italy during 1979 to 1993.

${ }^{4}$ On the idea of monetary constitution, see Glasner (1989:206-7), Leijonhufvud (1983), and Barro (1982:
} 
Another entirely different type of monetary constitution would be a regime of fiat money with a Friedman monetarist rule which specifies a fixed rate of growth of some monetary aggregate. The first type of monetary constitution is based on the convertibility of the national currency into some asset that the monetary authority cannot create at will while the second is based on the limit on the quantity of currency issued. Both regimes constraint the power to issue money within well-defined limits and reduce price uncertainty.

This paper is divided into three parts. First, we examine advantages and shortcomings of the two principal proposals of monetary constitution for Brazil - the currency board and independent central bank — in the light of monetary history of Brazil. Second, we outline a monetary constitution inspired by João Pandiá Calógeras' Monetary Project (1926) with the only purpose of shedding light on the basic principles involved in the design of a monetary constitution aimed at controlling effectively the power to create money and at reducing inflation. Finally, we present some concluding remarks.

\section{PROPOSALS OF MONETARY CONSTITUTIONS}

The two principal competing proposals to reform Brazilian monetary institutions - the currency board and the independent Central Bank - were attempted and they failed to deliver a stable currency. There were two efforts to establish a currency board type monetary system, in 1906 and 1926, and two attempts to set up an independent central bank, in 1923 and 1964. These policy experiments provide important lessons for the present debate and for the future of Brazilian monetary institutions.

The currency board is the most developed proposal, as regards its institutional details, for changing the Brazilian monetary system ${ }^{5}$. The main characteristic of this monetary constitution is that the board stands ready to exchange domestic currency for the foreign reserve currency at a specified and fixed rate. To perform this function the board is required to hold liquid and realizable financial assets in the reserve currency at least equal to the value of the domestic currency. Actually, the currency board regime is a Gold Standard regime in which a foreign reserve currency substitutes for gold.

The institutional design of the currency board is simple: it is an autonomous agency separated from the government, administered by a board of directors with long mandates, and with only one statutory objective: exchange domestic currency for a specified foreign currency at a fixed rate. The board deals only with the banking system (through a number of dealers to make operations easier and faster), and

\footnotetext{
${ }^{5}$ Lara Resende (1992) and Lemgruber (1992) have advocated the currency board. For a clear and concise explanation on Currency boards, see Walter (1991). For a review of the recent policy experiments with Currency boards, see Bennett (1994).
} 
only the banking system is allowed to exchange domestic currency for the foreign currency. In addition, the board cannot finance the government directly or buy public securities.

Therefore, the Central Bank's function to issue currency is delegated to the currency board while those functions of a central bank that are not delegated to a currency board are handled in a variety of ways. For example, in Singapore there are two main central banking institutions: the Board of Commissioners of Currency and the Monetary Authority of Singapore, set up in 1967 and 1970, respectively. The Board of Commissioners of Currency operates an orthodox currency board while the Monetary Authority of Singapore is responsible for the bulk of central banking functions and has a wide range of supervisory and regulatory powers (Collyns, 1983: 18). On the other hand, in Estonia, functions other than the currency board ones, such as lender of last resort and bank supervision, are operated by separate governmental agencies (Osban \& Villanueva, 1993).

The currency board proposal has a number of attractive advantages: simplicity, transparent operations and, most important, avoidance of deficit financing. In addition, the supporters of this option argue that the currency board would borrow the credibility of the foreign currency reserve and the money supply would adjust itself to the demand for money. Monetary policy would no longer be discretionary, and inflationary expectations and interest rates would converge rapidly to lower levels.

The main shortcomings of the proposal are: risk of overvaluation of the exchange rate and inelasticity of supply of currency to cope with financial panics. First, to avert the overvaluation of the exchange rate, the currency board system needs the economy be very open (large proportion of tradable goods), and flexible nontradable goods prices (principally, nominal wages). In the absence of flexible nominal wages, the system needs substantial increases in productivity to accommodate sticky nominal wages. There is every likelihood that a residual inflation in non-tradable goods would bring about substantial appreciation of the exchange rate which would reduce exports and economic growth. In addition, if the appreciation of the currency were significant, the pressure to devalue would be great and the currency board's credibility might be badly damaged, with negative consequences for price expectations. Second, the currency board system may be too rigid in case of general financial panic, when the monetary authorities would be called upon to support financial institutions in difficulties (Gudin, 1976: 221-3).

The historical experience with convertibility-type of monetary system is not encouraging for Brazil: it failed overwhelmed by external shocks. The first attempt to adhere to the Gold Standard was the establishment of an Exchange Fund in December 1906. The passionate debate over the advantages of the Exchange Fund became a dispute between urban sectors, who wanted a deflation and an appreciation of the exchange rate to the 1847 parity of 27 pence per mil-réis, and the agricultural sectors, who proposed monetary expansion and exchange stability at a more realistic rate. Eventually, the exchange rate was fixed at 15 pence per milréis. Actually, the commitment to the Gold Standard was partial as only the notes 
issued by the Exchange Fund were convertible at a fixed exchange rate. This rule did not apply to a significant stock of fiat money issued by the Treasury. The operation of the exchange mechanism depended on continuous external capital inflows. When the First World War interrupted the flows of goods and capital, the system collapsed as the exchange rate became unsustainable. The failure of the Exchange Fund was followed by a decade of fiat currency issued by the Treasury and by a short-lived Central Bank experiment. In 1926, an attempt was made to re-establish the Gold Standard. This second experiment was overwhelmed by the Great Depression in 1929-306.

As an alternative to the currency board, a number of economists have proposed to establish an independent Central Bank with powers to control the supply of money ${ }^{7}$. This stream points out correctly that, in Brazil, the present organization of the monetary authority gives the government unlimited power to issue currency to finance its deficits, causing monetary instability and price uncertainty. In addition, various empirical studies for industrialized countries suggest that there is a relationship between greater independence of the monetary authorities and lower inflation (Cukierman et al., 1992; Alesina, 1989; and Burdekin \& Laney, 1988).

However, there are doubts about the effectiveness of the independence of the Central Bank. First, while the supporters of this proposal would grant greater autonomy to the Central Bank, they do not spell out any rule to guide monetary policy, which would depend entirely upon the central bank's board of directors. Second, the independence of the monetary authorities is only a necessary but not sufficient condition to control money supply and to reduce inflation. There is no guarantee either that an independent central bank would resist political pressure to finance the public deficit or that it would use its monopoly to issue currency wisely ${ }^{8}$.

The monetary history of Brazil underlines the challenges to the establishment of independent monetary authorities: independent central banking experiments ended either overridden by powerful governments or overwhelmed by the financing needs of the government. The first independent central bank experiment was short lived, 1923-26. The Central Bank Charter was approved in January 1923 and its operations began in July 1923. The charter gave substantial powers to the Central Bank to control currency issue: it established that the Central Bank would issue notes backed $1 / 3$ by gold and $2 / 3$ by securities, and the central bank's credit to the government would be limited to a quarter of the tax revenues projected in the budget and should be paid back during the fiscal year. However, the President of the Republic continued to have a strong influence on monetary policy decisions

\footnotetext{
${ }^{6}$ For a detailed account of the two experiments with the Gold-Standard, see Neuhaus (1975: 27-44 and 81-95; and 1978).

${ }^{7}$ Among others, Paulo Rabello de Castro, Antonio Carlos Brandão and José Julio Senna stand out. See Carlos de Brito and Rabello de Castro (1992: 85-8).

${ }^{8}$ See Goodhart (1992) for a critical overview on Central Bank independence.
} 
and opted for a deflation in 1925-26, bringing about a sharp economic contraction and exchange rate appreciation. In 1926, the newly elected President of the Republic decided to end the experiment of an independent Central Bank and to reestablish the Gold Standard (Neuhaus, 1975: 60-80). This delayed the important institutional development of a central bank, which was taking place in other developed countries, until 1964, leaving monetary policy in the hands of the Treasury (Neuhaus, 1975: 147-9).

The second attempt to establish an independent central bank took place in the early sixties, but it also resulted in failure. In 1964-67, Roberto Campos and Octávio Gouvea de Bulhões conducted far-reaching monetary and fiscal reforms. An autonomous Central Bank was established with powers to conduct monetary policy. Its board of governors could not be fired (six-year mandates) and a maximum ceiling of $10 \%$ for money growth was established. To assure better coordination between fiscal and monetary policies, a National Monetary Council was also established and chaired by the Finance Minister, but with members of the Central Bank in the majority ${ }^{9}$. Therefore, the monetary authority had a fairly influential say on policy affairs at that time. As a matter of fact, the central bank governor voted against many measures that the Ministry of Finance put forward in the National Monetary Council.

However, in 1967, soon after Campos and Bulhões left the administration, the Central Bank governor was removed after confronting the military government. In 1971, the government ordered the central bank to finance the public sector deficit automatically ${ }^{10}$. There was no longer need to make provisions in the budget to pay interest on debt which was financed either by issuing money or public debt. That left the door open to imprudent fiscal policies. Nevertheless, inflation was low until the first oil-price shock in 1973 because of the lasting effects of the CamposBulhões institutional reforms: as the budget deficits were small and the economy was growing, the deficits were easily financed through borrowing in the domestic and external financial markets without pressing the monetary base too much. In 1974, the constitution of the Monetary Council was changed to give the Ministry of Finance overwhelming control over the Central Bank ${ }^{11}$. The expansion of public investment during the 1970s and early 1980s made it extremely difficult to control public expenditures and, as a result, the federal government had to resort to unsustainable external borrowing.

With the world debt crisis of 1982, the government was forced to shift from external borrowing to domestic borrowing to finance its deficit. In the mid-eighties, the increasing public borrowing requirements forced the Central Bank to roll over the public debt and finance the Treasury on a daily basis. As uncertainty regarding both the public debt and inflation rose, the non-financial private sector demand for

\footnotetext{
${ }^{9}$ See Law n. 4.595 of December 31, 1964. For a critical appraisal of this law, see Gudin (1976: 280-82).

${ }^{10}$ See Complementary Law No. 12 of November 8, 1971.

${ }^{11}$ See Law n. 6.045 of May 15, 1974.
} 
public bonds declined and, as a consequence, intermediary financial institutions lacked reserves to carry over their holdings of public bonds. The Central Bank stepped in and made repurchase agreements with the financial institutions by which, if a financial intermediary could not finance its portfolio of public bonds, the Central Bank automatically bought it back. This mechanism amounted to an instantaneous monetization of the public debt and money became completely endogenous ${ }^{12}$

As financial institutions could transform public bonds into currency and vice versa without any significant risk of capital loss, and the administrative costs were low given the use of computers, the public debt became money for all practical purposes. Banking deposits backed by public bonds, paying daily yields and offering instantaneous convertibility into currency, became widespread ${ }^{13}$. Holdings of M1 fell from $15.6 \%$ to $2.4 \%$ of GDP and the holdings of public debt increased from $5 \%$ to $14 \%$ of GDP during the $1970-92$ period. This institutional framework turned out to be very unstable when inflation accelerated, prompting the government to confiscate a portion of its securities each time it announced a stabilization plan as a means of reducing its financing requirements ${ }^{14}$. These measures reduced confidence in government bonds and, as a result, demand increasingly shifted toward other assets, increasing the cost of financing the public debt. Under these conditions, monetary policy became thoroughly ineffective in stabilizing prices.

\section{OUTLINE OF A MONETARY CONSTITUTION}

The study of the two main proposals to reform the Brazilian monetary constitution suggests: (a) The orthodox currency board may be a superior alternative to control money expansion effectively and to prevent public deficit financing, however, it may cause an overvaluation of the currency and may be too rigid to deal with financial panics; (b) The independent central bank option is superior to cope with government borrowing requirements and financial panic, however, it is clearly inferior in terms of preventing deficit financing which can damage its credibility and its ability to control money expansion. To overcome the problems of both proposals, as suggested by Calógeras (1926), we should start by addressing two

\footnotetext{
12 The empirical evidence on the exogeneity of money is not conclusive. A brief review of the empirical evidence can be found in Mascolo \& Pereira (1988). It is worth pointing out that the econometric evidence of money not causing prices in the Granger-Sims definition does not mean money does not account for inflation. Pastore (1990) argues correctly that the passiveness of money supply in some periods arise out of the fact that the central bank renounced its control of the quantity of money. See Ronci \& Tullio (1996) for a detailed account of monetary policy during 1980-92.

${ }^{13}$ A detailed explanation of how the public debt became quasi-money can be found in Pastore (1990) and Rabello de Castro \& Ronci (1990).

${ }^{14}$ The loss of capital due to changes of indexation rules are estimated at $80 \%$ of the real value of the debt between 1975 to 1992. See Ronci (1993: 95).
} 
different questions: the monetary stabilization and the exchange rate parity with a foreign currency reserve. The first question has to do with the effective control of money expansion in order to reduce price inflation. Regarding the exchange rate parity, there are grounds to argue for some flexibility because of the degree of openness of the Brazilian economy in terms of imports and exports of goods and services is still low compared to other industrialized countries, and non-tradable inflation (in particular, nominal wages) could be sizable ${ }^{15}$. On this matter, a limited degree of exchange rate flexibility is prudent to avert excessive overvaluation of the domestic currency.

There are two principles that should be considered in order to control effectively the power to create money. The first principle, as Ciampi correctly pointed out, is that the power to create money should be completely independent from the agents that determine government expenditure. This principle is a necessary condition for controlling money creation and follows from the observation that, in general, the principal cause behind excessive monetary expansion is government deficit financing. The second principle should be precise legal restrictions to control the power to create money in the long-term, although we recognize that some limited flexibility is needed in the short run to accommodate supply shocks. The second principle follows from the fact observed by Friedman that inflation is always a monetary phenomenon and cannot persist once there are restrictions to create money.

\section{Board of Commissioners of Currency}

Regarding the first principle, one possible way to control the power to create money, inspired by Calógeras' Monetary Project (1926), would be to divide the monetary authority into two agencies ${ }^{16}$ : (a) A Board of Commissioners of Currency with exclusive power to issue currency and set the exchange rate ${ }^{17}$; and $(\mathrm{b})$ A Central Bank to administer the public debt, regulate and supervise the financial institutions, and administer the deposit insurance fund. To separate the power to create money and the agents that determine public expenditure and prevent financing the public deficit by printing money, the Board of Commissioners of Currency would be prohibited from buying or selling public sector securities and would carry out all its operations by means of buying and selling foreign currency. The Board of Commissioners of Currency would place part of the currency issue in

\footnotetext{
${ }^{15}$ For example, the share of imports and exports in GDP was only $15 \%$ in Brazil compared with 36\% in Italy in 1991.

${ }^{16}$ This proposal was put forward by Murtinho (1994) and Leijonhufvud (1983). It is similar to the one advanced by Lopes (1989: 77-90). However, while Lopes would create a department in the Central Bank to control the currency issue, our proposal creates an independent separate agency to control currency issue. This difference is no minor matter since we believe that in the case of Brazil Lopes' institutional framework would be beset with the problem of credibility.

17 Of course, as it has become the custom, the members of the Board would have long irrevocable mandates to protect them from political pressure.
} 
circulation by means of buying and selling foreign currency to licensed financial institutions at a pre-announced exchange rate, and hand over part of the currency issue to the Central Bank (of course there should be a ceiling on currency issues, see below). The Central Bank would treat this currency issue, that is not in circulation, as if it were foreign reserves and would pursue expansionary open-market operations as long as it had excess reserves on hand; the Central Bank would have to build up reserves before it could do it again. An important aspect of the proposal is that it does not require the fixing the exchange rate once and for all as the orthodox currency board does.

The second principle to be followed is precise legal restrictions to control the power to create money. One simple rule among various would be establishing a quantitative ceiling on currency issues. The advantages of establishing a ceiling for currency issue are its simplicity and compatibility with various monetary and exchange rate operational procedures. As an operational procedure, the Board of Commissioners of Currency could adopt a wide enough crawling exchange rate band which central parity would equal the difference between the authorities' inflation target and a forecast of foreign inflation for the next year ${ }^{18}$. The main virtue of the forward-looking exchange rate band is that provides a nominal anchor for inflation expectations, despite the exchange rate flexibility that it affords ${ }^{19}$. It is also worth noting that there would be no conflict between the Board of Commissioners of Currency's issues and Central Bank's open market operations because the Central Bank would carry out open-market operations (selling/buying government securities) only up to the limit of its reserves of domestic currency ${ }^{20}$.

The present proposal has an historical precedent. The Peel's Bank Act of 1844 divided the Bank of England into two departments: an Issuing Department and a Banking Department. The Issuing Department operated according to the Gold Standard rule rather than a currency issue ceiling; it issued notes as a proportion of its gold holdings. The Banking Department performed stabilization policy giving credit, buying and selling public bonds with the note issue as the base for the rest of the banking system. The Banking Department reserves were formed by the amount of Issue Department notes not in circulation. Therefore, the Banking Department was not able to buy whatever quantity of public bonds it wanted to finance the public deficit; it could buy only up to the limit of its reserves. This monetary framework worked fairly well for 70 years until the outbreak of the First World War.

\footnotetext{
18 A wide crawling exchange rate band and the ability of the Board to change the level of the band mid" point are important to deter speculative attacks on the exchange rate since the amount of foreign currency reserves is limited.

${ }^{19}$ See Bufman \& Leiderman (1996) for details on setting inflation targets and exchange rate bands.

${ }^{20}$ This, however, does not mean that open-market operations would have no impact at all: actually the ability of the Central Bank to influence the level of real credit and business cycle within limits would be enhanced because future price expectations would become more inelastic as the new institutional framework builds up its credibility. On this point, see Leijohufvud (1983).
} 


\section{Lender of Last Resort Role and Regulation and Supervision of Banks}

One important aspect of the proposal is the separation of the power to create money - and consequently the lender of last resort role — from the regulation and supervision of banks: while the Board of Commissioners of Currency would have the power to create money, the Central Bank would regulate and supervise banks. The separation may greatly facilitate the independence of the Board of Commissioners of Currency and improve the supervision of banks. As bank regulation and supervision is an activity closely related with general governmental authority, if the currency issuing agency assumes regulatory authority, it will get involved in the exercise of governmental authority which will certainly involve the Board of Commissioners of Currency in partisan politics and, therefore, endanger its independence (Heller, 1991).

With regards to the monetary authorities' role as a lender of last resort (Goodhart, 1990: 43 and 86), in the case of general financial panic, the currency ceiling (given by the amount of total foreign currency reserves) may be too rigid and it may be advisable to suspend temporarily the currency ceiling limit. In this respect, the Board of Commissioners of Currency should follow strictly the Bagehot's rule: to prevent illiquid banks from closing, the monetary authority should lend on any good collateral at a penalty interest rate above the market rate, and, once the panic is over, bankrupt banks (which total assets are less than total liabilities) should be closed (Bagehot, 1991: 96-7). These principles should be stated in advance and followed in a crisis. It is worth pointing out that Bagehot's rule is consistent with monetary stability: during a crisis, supply of money would respond to the demand for money above the ceiling; when the crisis passes, discounts are paid and growth of money is again controlled. England during the Peel's Act illustrates the application of Bagehot's rule: the act was suspended during the banking crises of 1847, 1857 and 1866, when the Bank of England was authorized to exceed the legal limit of note issue. Actually, suspending the Peel's Act was sufficient to dominate the financial panic, except in 1857 (Gudin, 1976: 230-1).

With regards to the regulation and supervision of banks to prevent financial panic, critics argue that there is an understanding that monetary authorities would not allow large commercial banks to fail and such a guarantee creates a serious problem of moral hazard, as bank institutions feel safer about engaging in reckless lending bringing about financial instability (Glasner, 1989: 183-7; and Dowd, 1988: 40-2). The establishment of state-guaranteed deposit insurance has made this problem even worse. The example of Brazilian state banks is telling: state banks have usually bent to political pressure and overextended lending to local governments, getting into serious financial problems and forcing the Central Bank to bail them out by printing money (actually, state banks became issuing banks for their respective local governments). To deter financial institutions from engaging in reckless 
lending, it may help to change the emphasis from supervision to disclosure of financial institution information and to limit the deposit insurance claims ${ }^{21}$.

\section{CONCLUSIONS}

The proposal is not the definitive bill of a monetary constitution: as the proverb says, "there are several ways of skinning a cat" and our proposal is one of the ways, though plausible ${ }^{22}$. The purpose of our proposal is only to shed light on the various aspects involved in the design of a monetary constitution and further our understanding of them. Notwithstanding the particular institutional framework, there are three basic principles that should be considered:

a) Separation between the power to create money and the agents that determine public expenditure;

b) Precise legal restrictions to control the power to create money, although we recognize that some limited flexibility is needed in the short run to accommodate supply shocks;

c) Separation of the power to create money (and as consequence lender of last resort role) from regulation and supervision of banks.

The monetary constitution will have to be supported by greater openness of the economy, investments to increase productivity, and a balanced public budget. On this last point, Calógeras' remark is as valid today as 70 years ago: "the foundation of all (monetary) projects is a balanced public budget" (Calógeras, 1926). In addition, the outcome of any reform of monetary constitution will depend partly on the understanding of the society and its representatives and policy makers that monetary and price stability are valuable public goods.

\footnotetext{
${ }^{21}$ Limiting insurance claims, the so-called stop-loss clause, has been the usual way the insurance industry deals with moral hazard problems. See Goodhart (1989a) and Rolnick (1993) for a proposal to reform deposit insurance by limiting insurance claims and introducing co-insurance for large depositors. 23 The amendments to the monetary reform of July 1st, 1994 would be minimal: there would be no major difficulty in passing a law delegating the Central Bank of Brazil's power to issue currency and in establishing a legal ceiling on currency issue immediately (this is necessary to comply with article 164 of the Constitution). The Board of Commissioners of Currency could initiate operations immediately using the Central Bank facilities and technical support by means of a contract between the two institutions. The Congress would supervise monetary policy, but would not be allowed to change the currency issue ceiling; and the Central Bank of Brazil would carry on all their operations normally without disruptions, except for those operations delegated to the Board of Commissioners of Currency.
} 


\section{REFERENCES}

ALESINA, Alberto (1989) "Politics and business cycles in industrial democracies", Economic Policy, apr.

BAGEHOT, Walter (1991) Lombard Street: A Description of the Money Market. Philadelphia, Orion Editions (reprint of the 1873 edition).

BARBOSA, Fernando de Holanda \& VALLS PEREIRA, Pedro (1989) “O Insucesso do Plano Cruzado: a Evidência Empírica da Inflação 100\% Inercial para o Brasil”, in BARBOSA, Fernando de Holanda \& SIMONSEN, Mario Henrique (eds.) Plano Cruzado: Inércia versus Inépcia. Rio de Janeiro, Globo, pp. 55-72.

BARRO, Robert J. (1982) "United States Inflation and the Choice of Monetary Standard", in HALL, Robert E. (ed.) Inflation: Causes and Effects. The University of Chicago Press, pp. 99-110.

BENNETT, Adam (1994) “Currency Boards: Issues and Experiences”, IMF Paper on Policy Analysis and Assessment, sep.

BUFMAN, Gil \& LEIDERMAN, Leonardo (1996) "Searching for Nominal Anchors in Shock-Prone Economies in the 1990s: Inflation Targets and Exchange Rate Bands", in HAUSMANN, R. \& REISEN, H. (eds.) Securing Stability and Growth in Latin America. Paris, OECD and Inter-American Development Bank.

BURDEKIN, Richard C. K. \& LANEY, Leroy O. (1988) "Fiscal Policy making and the Central Bank Institutional Constraint”, Kyklos, vol. 41, pp. 647-662. CALÓGERAS, João Pandiá (1926) Projeto Monetário, dec.

CARLOS DE BRITO, Paulo \& RABELLO DE CASTRO, Paulo (1992) Este país tem ieito? Rio de Janeiro, Rio Fundo.

COLLYNS, Charles (1983) "Alternatives to the Central Bank in the Developing World". Occasional Paper

n. 20, International Monetary Fund, jul.

CUKIERMAN, Alex, WEBB, Seven B. \& NEYAPTI, Bilin (1992) "Measuring the independence of central banks and its effects on policy outcomes”, The World Bank Economic Review, n. 6, vol. 3, PP. 353-98.

DOWD, Kevin (1988) Private Money: The Path to Monetary Stability. London, The Institute of Economic Affairs.

FRIEDMAN, Milton (1963) Dollars and Deficits. Englewood Cliffs, N.J., Prentice-Hall.

GLASNER, David (1989) Free Banking and Monetary Reform. Cambridge University Press.

GOODHART, Charles (1996) “Central Bank Independence”, in LANGONI, Carlos Geraldo, FERRER JR., James \& RONCI, Marcio The Quest for Monetary Stability. Rio de Janeiro and Washington D.C., Getulio Vargas Foundation and George Washington University.

GOODHART, Charles (1990) The Evolution of Central Banks. Cambridge, Massachusetts, The MIT Press.

GOODHART, Charles (1989) “Bank Insolvency and Deposit Insurance: A Proposal”, London School of Economics (manuscript).

GOODMAN, John B. (1992) Monetary Sovereignty: The Politics of Central Banking in Western Europe. Ithaca and London, Cornell University Press.

GUDIN, Eugênio (1976) Princípios de Economia Monetária. Rio de Janeiro, Agir, vol 1.

HELLER, H. Robert (1991) "Prudential Supervision and Monetary Policy", in DOWNES, Patric \& VAEZ-ZADEH, Reza (eds.) The Evolving Role of Central Banks. Washington, International Monetary Fund, pp. 64-5.

LEIJONHUFVUD, Axel (1983) "Constitutional constraints on the monetary powers of government", Economia delle Scelte Pubbliche, n. 2.

LEMGRUBER, Antônio Carlos (1992) “A inflação do cruzeiro sem lastro”, Rio de Janeiro (manuscript). LOPES, Francisco (1989) O Desafio da Hiperinflação. Rio de Janeiro, Campus.

MASCOLO, João Luiz \& VALLS PEREIRA, Pedro (1991) “Testes para exogeneidade da moeda”, Pesquisa e Planejamento Econômico, vol. 21, n. 2, pp. 377-96. 
MURTINHO, Joaquim (1994) “Caixa de Estabilização para a Nova Moeda”, Conjuntura Econômica, p. 7 , maio.

NEUHAUS, Paulo (1978) “A inflação brasileira em perspectiva histórica”, Revista Brasileira de Economia, Rio de Janeiro, vol. 32, n. 2, pp. 293-315, abr/jun.

NEUHAUS, Paulo (1975) História Monetária do Brasil: 1900-45. Rio de Janeiro, Instituto Brasileiro de Mercado de Capitais.

OSBAND, Kent \& VILLANUEVA, Delano (1993) “Independent Currency Authorities”, IMF Staff Papers, vol. 40, n. 1, mar.

PASTORE, Affonso Celso (1990) "Inflação e expectativas com política monetária numa regra de taxa de juros”, Revista Brasileira de Economia, Rio de Janeiro, vol. 44, n. 4, pp. 499-528, oct/dec.

PASTORE, Affonso Celso (1990) "A Reforma Monetária”, in FARO, Clovis de (ed.) Plano Collor: Avaliações e Perspectivas. Rio de Janeiro, Livros Técnicos e Científicos.

RABELLO DE CASTRO, Paulo \& RONCI, Marcio (1990) “A Equação Monetária: O Equívoco Central do Plano Collor”, in FARO, Clovis de (ed.) Plano Collor: Avaliações e Perspectivas. Rio de Janeiro, Livros Técnicos e Científicos.

RESENDE, André Lara (1992) “O Conselho da Moeda: Um Órgão Emissor Independente”, Revista de Economia Política, jul.

ROLNICK, Arthur J. (1993) “Market Discipline as a Regulator of Bank Risk”, in RANDALL, Richard E. (ed.) Safeguarding the Banking System in an Environment of Financial Cycles. Proceedings of a Symposium held at the Federal Reserve Bank of Boston, nov.

RONCI, Marcio \& TULLIO, Giuseppe (1996) "Brazilian inflation from 1980 to 1993: Causes, Consequences, and Dynamics”, Journal of Latin American Studies, sep.

WALTER, Alan (1991) “Currency Boards”, New Palgrave Dictionary of Economics. pp. 740-2.Revista de Economia Política, vol. 20, n o 1 (77), janeiro-março/2000 